\title{
VYBRANÉ ASPEKTY ZAČATIA KONANIA O VYVLASTNENÍ
}

\section{SELECTED ASPECTS OF THE COMMENCEMENT OF EXPRIOPRIATION PROCEEDINGS}

\author{
Lukáš Tomaš \\ Univerzita Pavla Jozefa Šafárika v Košiciach, Právnická fakulta
}

https://doi.org/10.33542/SIC2019-2-07

\begin{abstract}
ABSTRAKT
Predmetom predkladaného článku je analýza vybraných aspektov začatia konania o vyvlastnení, ktoré je nevyhnutným predpokladom realizácie rozhodovacích postupov podl'a zákona č. $282 / 2015$ Z. z. o vyvlastňovaní pozemkov a stavieb a o nútenom obmedzení vlastníckeho práva knim a o zmene a doplneni niektorých zákonov v znení zákona č. 177/2018 Z. z. Autor sa v článku zameriava najmä na všeobecnú charakteristiku spôsobu začatia konania o vyvlastnení a analyzuje niektoré aspekty náležitostí návrhu na začatie konania o vyvlastneni a zásad konania o vyvlastnení. Článok v relevantných súvislostiach reflektuje na aplikačnú prax, prináša komparáciu s minulou právnou úpravou a naostatok formuluje určité úvahy $k$ vybraným traktovaným inštitútom.
\end{abstract}

\begin{abstract}
Selected aspects of the commencement of expropriation proceedings the subject of the submitted article is an analysis of selected aspects of the commencement of expropriation proceedings which is an essential prerequisite of the realization of decision-making procedures according to the act no. 282/2015 coll. On the expropriation of land and buildings and on the forced restriction on ownership rights as amended. The author focuses, in particular, on the general characteristics of the procedure of the commencement of expropriation proceedings and analyses certain aspects of the elements of the motion to commence the proceedings and principles of expropriation proceedings. The article reflects on the application practice in the relevant context, compares the current and the past legislation and, last but not least, phrases certain deliberations on the selected institutes.
\end{abstract}

\section{I. ÚVOD}

Vlastnícke právo je jedným zo základných súkromnoprávnych inštitútov, ktorý býva v podmienkach trhového hospodárstva označovaný ako základ celého súkromného práva. ${ }^{1}$ Takto vymedzenému charakteru vlastníckeho práva zodpovedá aj zakotvenie právnej ochrany vlastníckeho práva na ústavnej úrovni ${ }^{2}$ a na úrovni všeobecného súkromnoprávneho

\footnotetext{
1 Š KROBÁK, J. Rozhodovacie procesy na úseku územného plánovania, stavebného poriadku a vyvlastňovania. In VRABKO, M. a kol. Správne právo procesné. Osobitná čast'. 2. aktualizované a doplnené vydanie. Šamorín: Heuréka, 2018, s. 125.

2 Podla čl. 20 ods. 1 alinea 2 Ústavy SR č. 460/1992 Zb. v znení neskorších ústavných zákonov (d’alej len „Ústava SR“) vlastnícke právo všetkých vlastníkov má rovnaký zákonný obsah a ochranu.
} 
predpisu. ${ }^{3}$ Úroveň právnej ochrany vlastníka však nemožno absolutizovat' v tom zmysle, že by vlastníkovi zaručovala úplná nedotknutel'nost' vlastníckeho práva. ${ }^{4} \mathrm{Aj}$ v demokratickej spoločnosti za splnenia kumulatívne daných podmienok možno odôvodnit' obmedzenie či odňatie ${ }^{5}$ vlastníckeho práva. Jedným z právne reglementovaných nástrojov, prostredníctvom ktorých sa uskutočňuje zásah do vlastníckeho práva, je inštitút vyvlastnenia (expropriatio).

Vyvlastnenie sa realizuje prostredníctvom rozhodnutia o vyvlastnení ako výsledku konania o vyvlastnení (vyvlastňovacieho konania), t. j. procesného postupu správnoprávneho charakteru, ktorého účelom je uskutočnenie materiálnej úpravy vyvlastnenia, a ktorý je účinne upravený predovšetkým v zákone č. 282/2015 Z. z. o vyvlastňovaní pozemkov a stavieb a o nútenom obmedzení vlastníckeho práva $\mathrm{k}$ nim a o zmene a doplnení niektorých zákonov v znení neskoršieho predpisu (d’alej len ,zákon o vyvlastňovaní“). ${ }^{6}$ Kým teda rozhodnutie o vyvlastnení predvída predošlé zákonne konformné uskutočnenie konania o vyvlastnení, konanie o vyvlastnení sa nemôže uskutočnit' bez toho, aby zákonodarcom predvídaným a prikázaným spôsobom začalo. $\mathrm{V}$ tomto zmysle bude predmetom právneho výskumu objektivizovaného $\mathrm{v}$ tomto príspevku analýza niektorých aspektov inštitútu začatia konania o vyvlastnení, konkrétne

- predostrenie úvah o interakcii ústavno-právnej regulácie práva na súdnu a inú ochranu a inštitútu začatia konania o vyvlastnení (predovšetkým vo svetle ústavne významných účinkov začatia konania o vyvlastnení),

- analýza charakteristických čŕt spôsobu začatia procesných postupov na úseku vyvlastňovania a

- formulácia niektorých (východiskových) úvah k zásadám, ktorými sa spravuje konanie o vyvlastnení.

Pokial' ide o metodológiu výskumu práce, využívam najmä metódu analytickú, so zretel’om na relatívnu ,čerstvost““ právnej úpravy je v relevantných súvislostiach významne zastúpená i metóda komparatívna a metóda historická. Metóda vedeckej abstrakcie bola použitá s ciel’om eliminovat' náhodilé a irelevantné skutočnosti od relevantných a zákonitých aspektov analyzovanej administratívno-formálnej matérie. Vo vybraných statiach konfrontujem analyzované inštitúty (pre terajší nedostatok tunajších právno-aplikačných rezultátov $\mathrm{k}$ účinnej úprave) s použitel'nými závermi súdnej praxe vo vzt’ahu k predošlým expropriačným legislatívam, ako aj so závermi rozhodovacej praxe súdov Českej republiky.

\footnotetext{
Podl’a ustanovenia § 124 zákona č. 40/1964 Zb. Občiansky zákonník (d’alej len „Občiansky zákonník“) všetci vlastníci majú rovnaké práva a povinnosti a poskytuje sa im rovnaká právna ochrana. Podl’a ustanovenia $§ 126$ ods. 1 alinea 1 Občianskeho zákonníka vlastník má právo na ochranu proti tomu, kto do jeho vlastníckeho práva neoprávnene zasahuje.

4 Podobne FEKETE, I. Občiansky zákonník. Vel'ký komentár. 2. zväzok (Vecné práva, Zodpovednost’ za škodu a za bezdôvodné obohatenie). 2. aktualizované a rozšírené vydanie. Bratislava: Eurokódex, 2015, s. 87

5 Podmienky realizácie vyvlastnenia sa zakotvujú vo viacerých právnych predpisoch. Podla

- čl. 20 ods. 4 Ústavy SR vyvlastnenie alebo nútené obmedzenie vlastníckeho práva je možné iba v nevyhnutnej miere a vo verejnom záujme, a to na základe zákona a za primeranú náhradu;

- ustanovenia $\S 128$ ods. 2 Občianskeho zákonníka vo verejnom záujme možno vec vyvlastnit' alebo vlastnícke právo obmedzit', ak účel nemožno dosiahnut' inak, a to len na základe zákona, len na tento účel a za náhradu;

- ustanovenia § 2 ods. 1 zákona o vyvlastňovaní vyvlastnenie možno uskutočnit’ len (a) v nevyhnutnej miere, (b) vo verejnom záujme na účel ustanovený zákonom, pričom verejný záujem na vyvlastnení sa musí preukázat' vo vyvlastňovacom konaní, (c) za primeranú náhradu, a (d) ak ciel' vyvlastnenia nemožno dosiahnut' dohodou alebo iným spôsobom. Pozri tiež SEMAN, T. Správne právo hmotné. Všeobecná čast' II. Košice: Univerzita Pavla Jozefa Šafárika v Košiciach, 2006, s. 113 .

6 Procesná úprava vyvlastnenia je aj takmer tri roky od nadobudnutia účinnosti zákona o vyvlastňovaní obsiahnutá aj v zákone č. 50/1976 Zb. o územnom plánovaní a stavebnom poriadku (stavebný zákon) v znení neskorších predpisov (d’alej len „stavebný zákon“). Táto úprava ako rezíduum legislatívnych peripetií však na základe aplikácie interpretačného pravidla lex posterior derogat legi priori nie je účinná, t. j. treba ju vnímat' ako legislatívne superfluum (úpravu obsolétnu), ktoré bude odstránené azda prijatím nového stavebného zákona. $\mathrm{Z}$ uvedeného dôvodu nebudem venovat' úprave vyvlastňovania podl'a stavebného zákona (s výnimkou niektorých komparatívnych súvislostí a historických aspektov) pozornost'.
} 
V určitých pasážach predostieram i vlastné úvahy, hodnotiace závery a naostatok formulujem aj určité návrhy de lege ferenda.

\section{VÝZNAM A PRÁVNA ÚPRAVA ZAČATIA KONANIA O VYVLASTNENÍ, KONKURENCIA ZAČATIA KONANIA O VYVLASTNENÍ A ÚZEMNÉHO KONANIA}

Význam začatia konania o vyvlastnení možno vnímat' v dvoch rovinách, ktoré sa odlišujú stupňom abstrakcie, ale vo svojej podstate značia vyjadrenie toho istého účelu spočívajúceho v snahe o zamedzenie nezákonných zásahov do vlastníckeho práva.

V prvom rade je zákonné začatie konania o vyvlastnení nevyhnutným predpokladom (conditio sine qua non) právno-konformnej realizácie individuálnych rozhodovacích postupov administratívnoprávneho charakteru podl'a zákona o vyvlastňovaní a osobitných vyvlastňovacích predpisov. To platí tak pre vyvlastňovacie konanie $\mathrm{v}$ užšom slova zmysle (autoritatívne vyvlastňovacie konanie), pre konanie o určenie a priznanie primeranej náhrady za vyvlastnenie, ${ }^{7}$ ktoré možno nazvat' náhradovým vyvlastňovacím konaním, ako aj pre vyvlastňovacie konanie ako celok (vyvlastňovacie konanie v širšom slova zmysle). Začatie konania o vyvlastnení teda vytvára skutočný priestor pre uplatnenie zásady legality vyvlastňovacieho konania, ktorá sa určitým spôsobom precizuje v samostatnej zásade „niet vyvlastnenia bez vyvlastňovacieho konania“ (pozri nižšie).

V širšom zmysle sa prostredníctvom inštitútu začatia konania o vyvlastnení otvára priestor pre

- praktickú realizáciu ústavného práva na ochranu na inom orgáne Slovenskej republiky $\mathbf{v}$ zákonom ustanovenom prípade podl'a čl. 46 ods. 1 Ústavy SR,

- materiálne uplatnenie odkazovacej ústavnej normy obsiahnutej v čl. 46 ods. 4 Ústavy $\mathrm{SR}^{9} \mathrm{a}$

- prípadné domáhanie sa ochrany subjektívnych (vecných) práv súdnym prieskumom rozhodnutia o vyvlastnení v správnom súdnom konaní tak, ako to zakotvuje čl. 46 ods. 2 Ústavy SR. ${ }^{10}$ Ostatne zmienený význam začatia konania o vyvlastnení bude aktuálny v prípade, pokial' sa (parafrázujúc Tibora Semana) vyvlastňovací orgán (prípadne odvolací orgán) „zmýlii,“ pričom úlohou správneho súdu bude vlastne zistit’ dodržanie hmotnoprávnych a procesnoprávnych noriem orgánom verejnej správy $v$ jeho právnoaplikačnej činnosti a na základe tohto zistenia poskytnút' svojím (súdnym) rozhodnutím ochranu subjektívnym právam. ${ }^{11} \quad$ Kým účinky začatia konania o vyvlastnení možno (vo všeobecnom zmysle) vyvodit' už z ústavnej úpravy, bližšiu charakteristiku začatia vyvlastňovacieho konania a súvisiacich inštitútov ponecháva Ústava SR podústavným predpisom. Účinná právna úprava začatia konania o vyvlastnení je obsiahnutá najmä v ustanovení § 9 zákona o vyvlastňovaní,

GOGOVÁ, M., BUDJAČ, M. Historický kontext formovania inštitútu vyvlastnenia a jeho reflexia de lege lata. In Právny obzor, 2008, č. 1, s. 65.

8 Podla čl. 46 ods. 1 Ústavy SR každý sa môže domáhat' zákonom ustanoveným postupom svojho práva na nezávislom a nestrannom súde a v prípadoch ustanovených zákonom na inom orgáne Slovenskej republiky.

9 Podl'a čl. 46 ods. 4 Ústavy SR podmienky a podrobnosti o súdnej a inej právnej ochrane ustanoví zákon.

10 Podl'a čl. 46 ods. 2 Ústavy SR kto tvrdí, že bol na svojich právach ukrátený rozhodnutím orgánu verejnej správy, môže sa obrátit' na súd, aby preskúmal zákonnost' takéhoto rozhodnutia, ak zákon neustanoví inak. Z právomoci súdu však nesmie byt' vylúčené preskúmanie rozhodnutí týkajúcich sa základných práv a slobôd. Na margo ochrany vecných práv v správnom súdnom konaní treba dodat', že správny súd poskytuje ochranu všetkým subjektívnym právam, ktoré sú spojené alebo vyplývajú z preskúmavaného správneho aktu alebo činnosti orgánov verejnej správy, a to bez na ich verejnoprávnu alebo súkromnoprávnu povahu. Pozri bližšie FEČÍK, M. Komentár k § 5 Správneho súdneho poriadku. In BARICOVÁ, J. - FEČÍK, M. - ŠTEVČEK, M. - FILOVÁ, A. a kol. Správny súdny poriadok. Komentár. Bratislava: C. H. Beck, 2018, s. $68-69$.

11 SEMAN, T. Verejná správa v správnom súdnictve. Košice: Univerzita Pavla Jozefa Šafárika v Košiciach, 2016, s. 9, s. 10. 
ktorý vymedzuje všeobecné inštitúty týkajúce sa začatia konania o vyvlastnení, t. j. (i) spôsob začatia konania o vyvlastnení, (ii) náležitosti návrhu na začatie konania o vyvlastnení, (iii) prílohy $\mathrm{k}$ návrhu na začatie konania o vyvlastnení a (iv) vecnú koncentráciu vyvlastňovacích konaní (spojenie vecí). Zvláštna regulácia určitých aspektov začatia konania o vyvlastnení je upravená viacerými osobitnými predpismi administratívneho charakteru, tzv. osobitnými vyvlastňovacími predpismi. Pôjde najmä o zákon č. 319/2002 Z. z. o obrane Slovenskej republiky v znení neskorších predpisov (d’alej len „zákon o obrane Slovenskej republiky“") a zákon č. 669/2007 Z. z. o jednorazových mimoriadnych opatreniach v príprave niektorých stavieb dial'nic a ciest pre motorové vozidlá a o doplnení zákona Národnej rady Slovenskej republiky č. 162/1995 Z. z. o katastri nehnutel'ností (katastrálny zákon) v znení neskorších predpisov (d’alej len ,zákon o jednorazových mimoriadnych opatreniach $\mathrm{v}$ príprave niektorých stavieb dial'nic a ciest pre motorové vozidlá").

Pokial' ide o konkurenciu začatia konania o vyvlastnení a začatia územného konania, $v$ aplikačnej praxi vznikali názory, že rozhodnutie o vyvlastnení nehnutel'nosti by malo byt' $\mathrm{v}$ prípadoch, ked' právna úprava ${ }^{12}$ predvída vydanie územného rozhodnutie len pri existencii účelu vyvlastnenia, vydané ešte pred vydaním tohto územného rozhodnutia. $V$ takom prípade by teda začatie (a meritórne skončenie) vyvlastňovacieho konania nevyhnutne predchádzalo začatiu, prípadne zákonnému skončeniu územného konania. Tieto právne názory sa odôvodňovali najmä domnelým zložitejším charakterom vyvlastňovacieho konania a požiadavkou ochrany vlastníckeho práva. ${ }^{13}$ NSS sa $\mathrm{s}$ takouto argumentáciou a jej odôvodnením vo svojej ustálenej rozhodovacej praxi nestotožňuje, poukazujúc na skutočnost', že právoplatné územné rozhodnutie predstavuje zákonom normovaný predpoklad pre následné začatie vyvlastňovacieho konania. ${ }^{14} \mathrm{NSS}$ síce uznáva, že stavebný úrad v územnom konaní skúma základné podmienky pre možnost' vyvlastnenia ( $\mathrm{v}$ kontexte existencie účelu vyvlastnenia), ${ }^{15}$ takéto teoretické skúmanie však nie je predmetom územného konania a má charakter posúdenia predbežnej otázky. Toho dôsledkom je neprejudikovanie záveru o existencii podmienok vyvlastnenia pre prípadné konanie o vyvlastnení. ${ }^{16} \mathrm{~V}$ tejto súvislosti som názoru, že vyvlastňovací orgán posudzuje existenciu podmienok vyvlastnenia na kvalitatívne vyššej úrovni v porovnaní so správnym orgánom uskutočňujúcim územné konanie, a preto môže regulérne dospiet' $\mathrm{k}$ odlišným záverom $\mathrm{v}$ porovnaní so závermi územného konania. $\mathrm{K}$ argumentu domnelej vyššej náročnosti vyvlastňovacieho konania $\mathrm{v}$ porovnaní s územným konaním NSS uvádza: "Co se týče složitosti ř́zeni (územni oproti vyvlastňovacímu), nelze obecně stanovit, které z nich bude složitější. To bude záležet na okolnostech konkrétního případu." Pokial' ide o požiadavku ochrany vlastníckeho práva, NSS je názoru, že vo vzt’ahu $\mathrm{k}$ ochrane ústavne zarušeného vlastníckeho práva sa javí vhodnejším riešenie, pri ktorom je najskôr rozhodované v konaní, v ktorom sa do vlastníckeho práva zasahuje miernejším spôsobom. Takýmto konaním je konanie územné. Až v nadväznosti nato, ked' bude isté, že stavbu je možné v predpokladanej podobe na konkrétnom pozemku postavit', je na mieste pristúpit' $\mathrm{k}$ vyvlastneniu, ktoré je

12 Ustanovenie $§ 86$ ods. 3 zákona č. 183/2006 Sb. o územním plánovaní a stavebním řádu (stavební zákon) v znení účinnom do 31. decembra 2017, ustanovenie $§ 184$ a ods. 3 toho istého zákona v znení účinnom od 1. januára 2018, aj obsahovo obdobné ustanovenie $\S 38$ stavebného zákona.

13 Porov. argumentáciu sporových strán v rozsudku Najvyššieho správneho súdu Českej republiky (d’alej len „NSS“) sp. zn. 6 As 231/2016-40 zo dňa 22. marca 2017.

14 Vyplýva z rozsudkov NSS sp. zn. 2 As 21/2016-83 zo dňa 26. júla 2016, sp. zn. 10 As 294/2016-29 zo dňa 2. marca 2017, sp. zn. 6 As 231/2016-40 zo dňa 22. marca 2017, sp. zn. 1 As 93/2018 zo dňa 10. októbra 2018.

15 Z rozsudku NSS sp. zn. 6 As 231/2016-40 zo dňa 22. marca 2017: „Stavebni úřad v územním řizení zkoumá základní podmínky pro možnost vyvlastnění, tedy zda je pro konkrétní navrhovanou stavbu dán stavebním zákonem nebo jiným zvláštním zákonem vyvlastňovaci titul $v$ tom smyslu, že prodaný účel zákon připouští možnost pozemek $i$ vyvlastnit, resp. možnost zř́zení věcného břemene rozhodnutím vydaným v ř́zení o vyvlastnění pro př́pad, že nelze téhož dosáhnout smlouvou s vlastnikem pozemku."

16 Podobne rozsudok NSS sp. zn. 2 As 21/2016-83 zo dňa 26. júla 2016. 
citel'nejším zásahom do vlastníckeho práva. Právoplatné rozhodnutie o umiestnení stavby tak určí, ktoré pozemky a v akom rozsahu, pokial nedôjde $\mathrm{k}$ dohode $\mathrm{s}$ vlastníkom, môžu byt' predmetom následného konania o vyvlastnení."17 Tieto závery NSS aprobuje aj slovenská právna úprava, pretože jednou z príloh návrhu na začatie vyvlastňovacieho konania je aj právoplatné územné rozhodnutie alebo jeho úradne osvedčenú kópiu, ak účel vyvlastnenia vyžaduje vydanie územného rozhodnutia, vrátane kópie jeho grafickej časti, z ktorej je zrejmé umiestnenie stavby [ustanovenie $\S 9$ ods. 3 písm. g) zákona o vyvlastňovaní].

\section{SPÔSOB ZAČATIA KONANIA O VYVLASTNENÍ}

Všeobecnú úpravu spôsobu začatia konania o vyvlastnení obsahuje zákon o vyvlastňovaní v ustanovení $\S 9$ ods. 1. Konanie o vyvlastnení je bezvýnimočne návrhovým konaním, je preň teda príznačná dispozičná zásada. Povedané inými slovami, vyvlastňovacie konanie nemôže začat' vyvlastňovací orgán z úradnej moci (ex offo), a to ani v prípade, ak sú inak splnené materiálno-právne podmienky na uskutočnenie vyvlastnenia.

Pokial' ide o uplatnenie dispozičnej zásady s dôrazom na spôsob začatia vyvlastňovacieho konania, osobitné predpisy nepripúšt’ajú výnimky z dispozičnej zásady. So zretel’om na priebeh vyvlastňovacieho konania a rozhodnutie vo vyvlastňovacom konaní však nie je použitie dispozičnej zásady absolútne. Prelomením dispozičnej zásady v prospech zásady oficiality sú vybrané všeobecné procesné inštitúty konania o vyvlastnení, ktoré upravuje predovšetkým zákon č. 71/1967 Zb. o správnom konaní (správny poriadok) v znení neskorších predpisov (d’alej len "správny poriadok") ako všeobecný predpis o správnom konaní, a ktoré sú titulom všeobecnej subsidiarity správneho poriadku použitel’né aj v konaní o vyvlastnení. Takýmto prípadom môže byt' možnost' vyvlastňovacieho orgánu prerušit' konanie o vyvlastnení ex offo (ustanovenie § 29 ods. 1 správneho poriadku), možnost' vyvlastňovacieho orgánu pokračovat' v konaní, ktoré bolo predpísaným spôsobom prerušené, Z vlastného podnetu (ustanovenie $\S 29$ ods. 3 správneho poriadku) ${ }^{18}$ či možnost' Ministerstva dopravy a výstavby SR ako druhostupňového orgánu preskúmat' rozhodnutie o vyvlastnení mimo odvolacieho konania (ustanovenia $§ 65$ - $§ 68$ správneho poriadku).

Konkrétne vyjadrenie dispozičnej zásady so zretel'om na okamih začatia vyvlastňovacieho konania zakotvuje ustanovenie $\S 9$ zákona o vyvlastňovaní, podl'a ktorého konanie o vyvlastnení sa začína výlučne na písomný návrh vyvlastnitel’a. Vo vzt’ahu k návrhu na začatie konania o vyvlastnení možno z normatívnej úpravy substancovat'

1) formálne požiadavky na návrh,

2) materiálne požiadavky na návrh,

3) požiadavku spočívajúcu v potrebe podania návrhu oprávnenou osobou.

Ad 1)

Pokial' ide o formálne náležitosti návrhu, platí, že návrh na začatie konania o vyvlastnení možno podat' výlučne písomne. Zákon neustanovuje sprísnenú písomnú formu, ktorá by spočívala v potrebe iniciácie konania prostredníctvom zákonom či podzákonným predpisom predpísaného formulára.

Podrobnosti ohl'adom písomnej formy konania upravuje správny poriadok. Písomná forma podania bude zachovaná pri uskutočnení podania $\mathrm{v}$ listinnej podobe alebo $\mathrm{v}$ elektronickej

17 rozsudok NSS sp. zn. 6 As 231/2016-40 zo dňa 22. marca 2017. Ústavnú konformitu týchto záverov potvrdil aj Ústavný súd Českej republiky v uznesení sp. zn. III. ÚS 2506/17 zo dňa 5. septembra 2017.

18 Bližšie JAKAB, R. Priebeh správneho konania In JAKAB, R., MOLITORIS, P. Správne právo procesné. Košice: Univerzita Pavla Jozefa Šafárika v Košiciach, 2018, s. 119 a nasl. 
podobe. Návrh na začatie konania o vyvlastnení je podaním vo veci samej, preto pokial' bude urobený v elektronickej podobe bez autorizácie podl'a osobitného predpisu o elektronickej podobe výkonu verejnej moci, bude potrebné ho do troch pracovných dní doplnit' v listinnej podobe, $\mathrm{v}$ elektronickej podobe autorizovat' podl'a osobitného predpisu o elektronickej podobe výkonu verejnej moci, alebo ústne do zápisnice (ustanovenie $\S 19$ ods. 1 správneho poriadku). V opačnom prípade nastanú procesné dôsledky, ktoré zákon o vyvlastňovaní spája s imperfektnost'ou návrhu na začatie konania (vid' nižšie). Platná právna úprava nepripúšt’a začatie konania o vyvlastnení na základe ústneho podania, rovnako nie je prípustné vykonanie podania akýmkol'vek iným technicky vykonatel'ným spôsobom. Z hl'adiska úrovne ochrany vlastníckych práv a možných závažných hmotnoprávnych dôsledkov vyvlastňovacieho konania je zákonodarcom zvolený formalizmus namieste.

Ad 2)

Materiálne požiadavky (obsahové náležitosti) návrhu na začatie konania o vyvlastnení vymedzuje zákon o vyvlastňovaní v ustanovení $§ 9$ ods. $2 .{ }^{19}$ Charakter koncepcie náležitostí návrhu je imperatívny tak, aby bol tento návrh spôsobilý dostatočne spol'ahlivo identifikovat' všetkých účastníkov konania o vyvlastnení v rozsahu údajov podl’a správy katastra. Zámerom zákonodarcu je teda materiálne vybavenie návrhu na začatia konania $\mathbf{v}$ takom rozsahu, aby tento mohol viest' $k$ spol'ahlivému zisteniu skutkových okolností relevantných pre zákonný priebeh rozhodovacích postupov na úseku vyvlastňovania nehnutel'ností, vrátane určenia náhrady. Táto požiadavka sa následne odzrkadlí vo formálnych náležitostiach rozhodnutia o vyvlastnení, ktoré musí byt' jednoznačné a zrejmé (musí vylučovat' akékol'vek neurčitosti) a musí byt' v každom ohl'ade vykonatel'né. ${ }^{20} \quad \mathrm{~V}$ súvislosti s materiálnymi požiadavkami návrhu na začatie konania o vyvlastnení si bližšiu pozornost' zasluhuje vymedzenie účelu, na ktorý sa vyvlastnenie vo verejnom záujme navrhuje a odôvodnenie návrhu vyvlastnitel’a na vyvlastnenie. Orgány aplikácie práva v tejto súvislosti

19 Návrh musí obsahovat' (a) údaje o vyvlastnitel'ovi, a to meno a priezvisko, dátum narodenia, adresu trvalého pobytu (d’alej len „osobné údaje“) vyvlastnitel'a, ak je vyvlastnitel’om fyzická osoba, obchodné meno, adresu trvalého pobytu a adresu sídla, ak miesto podnikania nie je totožné s miestom trvalého pobytu, ak je vyvlastnitelom fyzická osoba podnikatel', názov, sídlo a identifikačné číslo organizácie a údaje o zápise v obchodnom registri alebo inom obdobnom registri, ak je vyvlastnitel'om právnická osoba, (b) údaje o vyvlastňovanom, a to dostupné osobné údaje, ak je vyvlastňovaným fyzická osoba, obchodné meno, adresu trvalého pobytu a adresu sídla, ak miesto podnikania nie je totožné s miestom trvalého pobytu, ak je vyvlastňovaným fyzická osoba - podnikatel', názov, sídlo a identifikačné číslo organizácie a údaje o zápise $\mathrm{v}$ obchodnom registri alebo inom obdobnom registri, ak je vyvlastňovaným právnická osoba, (c) údaje o tretej osobe, ktorej právo môže byt' vyvlastnením priamo dotknuté, a to osobné údaje, ak je tretia osoba fyzickou osobou, obchodné meno, adresu trvalého pobytu a adresu sídla, ak miesto podnikania nie je totožné s miestom trvalého pobytu, ak je tret’ou osobou fyzická osoba - podnikatel', názov, sídlo a identifikačné číslo organizácie a údaje o zápise v obchodnom registri alebo inom obdobnom registri, ak je tret'ou osobou právnická osoba, (d) označenie pozemku alebo označenie stavby, alebo ich častí, ktoré sú predmetom vyvlastnenia, a to podla údajov katastra nehnutel’ností alebo podl'a pozemkovej knihy, alebo inej obdobnej evidencie, alebo vyplývajúce $\mathrm{z}$ iných listín preukazujúcich vlastníctvo $\mathrm{s}$ identifikáciou parcely alebo s písomnou identifikáciou o stave údajov katastra nehnutel'ností pozemku a podl’a geometrického plánu, ak nehnutel'nost', ktorá je predmetom vyvlastnenia, nie je zobrazená v katastrálnej mape, alebo ak je predmetom vyvlastnenia čast' pozemku alebo čast' stavby už zobrazenej v katastrálnej mape alebo pri zriadení vecného bremena $\mathrm{k}$ časti pozemku alebo $\mathrm{k}$ časti stavby, (e) prehl'ad práv tretích osôb zapísaných v katastri nehnutel'ností alebo v pozemkovej knihe, alebo inej obdobnej evidencii, alebo, ktoré sú vyvlastnitel'ovi známe, ktoré sa viažu k pozemku alebo ku stavbe, ktorých sa vyvlastnenie týka, s osobitným označením tých práv, pri ktorých sa navrhuje obmedzenie alebo zánik súčasne s rozhodnutím o vyvlastnení, (f) údaj o sume predpokladanej náhrady za vyvlastnenie, ktorá pozostáva zo všeobecnej hodnoty pozemku alebo stavby, alebo všeobecnej hodnoty práva zodpovedajúceho vecnému bremenu určenej znaleckým posudkom, (g) dohodu vyvlastňovaného o rozdelení náhrady s tretími osobami, ktorým na vyvlastňovanom pozemku alebo na vyvlastňovanej stavbe viaznu vecné práva zanikajúce vyvlastnením, pokial' táto dohoda bola uzavretá pred podaním návrhu na vyvlastnenie a vyvlastnitel' má túto dohodu k dispozícii, (h) vymedzenie účelu, na ktorý sa vyvlastnenie vo verejnom záujme navrhuje a odôvodnenie návrhu vyvlastnitel'a na vyvlastnenie, (i) opis skutočností nasvedčujúcich tomu, že sú splnené podmienky vyvlastnenia podla § 2, (j) údaj o tom, v akej predpokladanej lehote vyvlastnitel' začne s užívaním vyvlastňovaného pozemku alebo vyvlastňovanej stavby na uskutočnenie účelu vyvlastnenia; ak ide o dočasné obmedzenie vlastníckeho práva k pozemku alebo ku stavbe vyvlastnením, aj čas tohto obmedzenia.

20 Porov. dôvodovú správu k zákonu o vyvlastňovaní. 
(hodno sa domnievat', že s ohl'adom na potrebu zabezpečenia ochrany pred nedostatočne odôvodnenými zásahmi do vlastníckeho práva celkom dôvodne) niekedy vyžadujú aj uvedenie spôsobu, ako hodlá vyvlastnitel' začat' uskutočňovanie účelu. K. Janderka tu uvádza, že začatie účelu vyvlastnenia je dané charakterom konkrétneho účelu podl'a osobitného zákona; vel'mi často to bude začatie stavby na základe právoplatného stavebného povolenia. Pokial' ide o inštitút "začatia stavby", v aplikačnej praxi vznikali pochybnosti o interpretácii tohto pojmu. "Začatím stavby" treba rozumiet' podl'a mienky NSS nie odovzdanie staveniska, vytýčenie sietí, aní skrývku ornice; začatím stavby sú činnosti, ktoré smerujú už nepochybne $k$ realizácii vlastnej stavby. ${ }^{21}$ Tento výklad NSS je aplikovatel'ný aj na slovenské pomery.

V porovnaní s predošlou úpravou náležitostí návrhu na začatie konania o vyvlastnení je účinná právna úprava odlišná

\section{- kvalitatívne a}

\section{- kvantitatívne.}

Kvalitatívna odchýlka spočíva $\mathrm{v}$ skutočnosti, že náležitosti návrhu na začatie konania o vyvlastnení podrobne vymedzuje výlučne zákon. Minulá právna úprava vymedzovala náležitosti návrhu na úrovni zákona len rámcovo, ${ }^{22}$ pričom podrobnejšia úprava bola ponechaná podzákonným právnym predpisom. ${ }^{23} \mathrm{~V}$ súčasnosti sú obsahové požiadavky na návrh na začatie konania o vyvlastnení upravené jediným právnym predpisom na úrovni zákona. S ohl'adom na dôslednú potrebu zabezpečenia právnej istoty $\mathrm{v}$ konaní o vyvlastnení možno túto zmenu hodnotit' pozitívne.

Pokial' ide o kvantitatívne modifikácie, platná právna úprava je v porovnaní so stavebným zákonom podrobnejšia a precíznejšia. Na rozdiel od predošlej úpravy musí návrh na začatie vyvlastňovacieho konania obsahovat' aj údaje o tretej osobe, ktorej právo môže byt' vyvlastnením priamo dotknuté, či prehl'ad práv tretích osôb zapísaných $\mathrm{v}$ katastri nehnutel'ností alebo v pozemkovej knihe, alebo inej obdobnej evidencii, alebo, ktoré sú vyvlastnitel'ovi známe, ktoré sa viažu k pozemku alebo ku stavbe, ktorých sa vyvlastnenie týka. Precizácia a kvantitatívne rozšírenie náležitostí návrhu na vyvlastnenie je odrazom potrieb aplikačnej praxe a môže mat' pozitívny dopad na ochranu práv väčšieho okruhu osôb, ktorých hmotnoprávneho postavenia sa vyvlastnenie môže viac či menej závažne dotknút'.

Úprava obsahových náležitostí návrhu na začatie konania podl’a zákona o vyvlastňovaní môže mat' (v závislosti od uhla pohl'adu)

- špeciálny charakter (lex specialis) alebo

- všeobecný charakter (lex generalis). ${ }^{24}$

Špeciálny charakter má táto úprava vo vzt’ahu $\mathrm{k}$ všeobecným náležitostiam podania v správnom konaní, ktoré vymedzuje ustanovenie $\S 19$ ods. 1 správneho poriadku (z podania musí byt' zrejmé, kto ho podáva, akej veci sa týka a čo sa navrhuje) ako všeobecný predpis

21 Pozri JANDERKA, K. Zákon o vyvlastnění. Poznámkové vydání. Praha: Linde, 2009, s. 36. Porovnaj tiež rozudok NSS sp. zn. 3 As 17/2008-68 zo dňa 24. septembra 2008.

22 Podl'a ustanovenia $\S 112$ ods. 3 stavebného zákona návrh na vyvlastnenie obsahuje označenie účastníkov konania, označenie vyvlastňovaného pozemku alebo stavby, navrhovaný rozsah a odôvodnenie požiadavky s uvedením účelu, na ktorý sa vyvlastnenie navrhuje, návrh náhrady a dôkaz o tom, že pokus o získanie práva k pozemku alebo $\mathrm{k}$ stavbe dohodou bol bezvýsledný.

23 Pozri ustanovenia § 30 vyhlášky Ministerstva životného prostredia Slovenskej republiky č. 453/2000 Z. z., ktorou sa vykonávajú niektoré ustanovenia stavebného zákona.

24 K pomeru lex generalis - lex specialis pozri DOBROVIČOVÁ, G. Právne normy. In BRÖSTL, A. a kol. Teória práva. Plzeň: Aleš Čeněk, 2013, s. 79; FILIČKO, V. Zásada lex specialis a jej ne/správna aplikácia v súdnej praxi. Vedlajší účastník v exekučnom konaní. In BRÖSTL, A., BREICHOVÁ LAPČÁKOVÁ, M., ŠTRKOLEC, M. (eds.) Základné zásady v rozhodovacej činnosti súdnej moci. Zborník vedeckých prác doktorandov. Košice: Univerzita Pavla Jozefa Šafárika v Košiciach, 2014, s. 271. 
(lex generalis). Pri vymedzení náležitosti návrhu na začatie konania o vyvlastnení nie je nevyhnutné odkazovat' na všeobecný predpis o správnom konaní, pretože požiadavky na podanie uvedené v ustanovení $\S 19$ ods. 1 správneho poriadku možno vyvodit' z úpravy zákona o vyvlastňovaní.

Náležitosti návrhu na začatie konania o vyvlastnení podl’a zákona o vyvlastňovaní majú všeobecný charakter (lex generalis) vo vzt’ahu k osobitným vyvlastňovacím predpisom (legi speciali). To znamená, že osobitné vyvlastňovacie predpisy môžu vymedzit' zvláštne náležitosti návrhu na vyvlastnenie na osobitné účely. V takom prípade bude potrebné, v závislosti od charakteru (špeciality) úpravy osobitného vyvlastňovacieho predpisu, aplikovat' bud' (i) výhradne úpravu osobitného vyvlastňovacieho predpisu, alebo (ii) úpravu zákona o vyvlastňovaní s odchýlkami ustanovenými osobitným vyvlastňovacím predpisom. Osobitným vyvlastňovacím predpisom na tieto účely je najmä zákon o obrane Slovenskej republiky, avšak len pokial' ide o vyvlastňovanie vo verejnom záujme na účely obrany v čase vojny alebo vojnového stavu, ${ }^{25}$ a zákon o jednorazových mimoriadnych opatreniach $\mathrm{v}$ príprave niektorých stavieb dial'nic a ciest pre motorové vozidlá. ${ }^{26}$

Pokial' ide o zákon o obrane Slovenskej republiky, úprava náležitostí návrhu na začatie vyvlastňovacieho konania vo verejnom záujme na účely obrany v čase vojny alebo vojnového stavu je komplexná, t. j. bez potreby podpornej aplikácie úpravy zákona o vyvlastňovaní. Vo vzt’ahu k návrhu na vyvlastnenie vo verejnom záujme na účely obrany v stave bezpečnosti ${ }^{27}$ zákon o obrane Slovenskej republiky obsahové požiadavky špeciálneho charakteru neurčuje. V tomto prípade teda bude potrebné riadit' sa právnou úpravou všeobecného predpisu o vyvlastňovaní.

Zákon o jednorazových mimoriadnych opatreniach v príprave niektorých stavieb dial'nic a ciest pre motorové vozidlá $\mathrm{v}$ ustanovení $\S 8$ ods. 2 ustanovuje, že návrh na začatie vyvlastňovacieho konania môže obsahovat' aj údaj o tom, či vyvlastnitel' navrhuje predbežnú držbu. Uvedená odchýlka súvisí so zakotvením nového inštitútu predbežnej držby. ${ }^{28}$ Pôjde o osobitú náležitost' návrhu na začatie vyvlastňovacieho konania, ktorej charakter je, podobne ako charakter inštitútu predbežnej držby, výhradne fakultatívny. Ak teda návrh na začatie konania o vyvlastnení neobsahuje navrhnutie predbežnej držby, z formálneho i obsahového hladiska bude predstavovat' dostatočný podklad pre začatie konania o vyvlastnení podl'a ostatne spomenutého zákona. Pokial' návrh bude obsahovat' návrh na predbežnú držbu, bude potrebné v návrhu vymedzit' aj práce, ktoré je potrebné na vyvlastňovanom pozemku alebo vyvlastňovanej stavbe vykonat'. Navrhnutie predbežnej držby sa však nespája výlučne s návrhom na začatie vyvlastňovacieho konania. Vyvlastnitel' môže navrhnút' predbežnú držbu aj po začatí vyvlastňovacieho konania. Ohl'adom ostatných náležitostí návrhu na začatie konania o vyvlastnení podl'a zákona o príprave niektorých stavieb dial'nic a ciest pre motorové vozidlá bude potrebné aplikovat' úpravu zákona o vyvlastňovaní.

\footnotetext{
$\S 23$ ods. 7 zákona o obrane Slovenskej republiky.

$\S 8$ ods. 2 zákona o príprave niektorých stavieb dialnic a ciest pre motorové vozidlá.

$\S 24$ a zákona o obrane Slovenskej republiky.

Inštitút predbežnej držby zaviedla novela zákona o jednorazových mimoriadnych opatreniach v príprave niektorých stavieb dial’nic a ciest pre motorové vozidlá vykonaná zákonom č. 139/2017 Z. z., ktorým sa mení a doplńa zákon č. 669/2007 Z. z. o jednorazových mimoriadnych opatreniach v príprave niektorých stavieb dial'nic a ciest pre motorové vozidlá a o doplnení zákona Národnej rady Slovenskej republiky č. 162/1995 Z. z. o katastri nehnutel’ností (katastrálny zákon) v znení neskorších predpisov v znení neskorších predpisov s účinnost’ou od 2. júna 2017.
} 
Ak osobitné vyvlastňovacie predpisy ${ }^{29}$ neupravujú náležitosti návrhu na začatie konania o vyvlastnení vôbec, treba postupovat' podl'a zodpovedajúcich ustanovení zákona o vyvlastňovaní.

Ad 3)

Subjekt oprávnený podat' písomný návrh na začatie konania o vyvlastnení je podl’a všeobecnej úpravy výlučne vyvlastnitel'. Legálna definícia vyvlastnitel'a je obsiahnutá v ustanovení $\S 3$ ods. 1 písm. a) zákona o vyvlastňovaní. Podl'a citovaného ustanovenia vyvlastnitel'om je ten, v prospech koho sa má uskutočnit' vyvlastnenie.

V aplikačnej praxi sa vo vzt'ahu $\mathrm{k}$ pertraktovanému inštitútu začatia vyvlastňovacieho konania vyskytli prípady, ked' iniciatíva na začatie vyvlastňovacieho konania vzišla zo strany subjektu odlišného od subjektu, $\mathrm{v}$ prospech ktorého sa navrhované vyvlastnenie malo uskutočnit'. Judikatórny záver o uvedených právno-realizačných nejasnostiach priniesol Najvyšší súd SR, ktorý v tejto súvislosti uviedol: „Navrhovatel’ súčasne musí byt' aktívne legitimovanou osobou vo vzt’ahu $k$ účelu vyvlastnenia. To znamená, že súčasne musí byt' osobou, ktorá má predmet vyvlastnenia využit’ na účel, na ktorý sa vyvlastňuje. Vyvlastnenie je originárny spôsob nadobudnutia vlastníckeho práva. V tomto prípade dochádza k prechodu (nie $k$ prevodu) vlastníckeho práva z vlastnika na navrhovatel'a vyvlastnenia ( $\$ 109$ ods. 2 prvá veta stavebného zákona). ${ }^{30}$ Stavebný zákon neupravuje možnost' vyvlastňovacím rozhodnutím upravit' prechod vlastníctva na inú osobu ako navrhovatel'a. Vyvlastňuje sa preto, aby vec nadobudol priamo navrhovatel' vo verejnom záujme a využíval ju v súlade $s$ kogentným účelom vyvlastnenia. “31 V súlade s citovaným rozhodnutím Najvyššieho súdu SR teda ani po účinnosti zákona o vyvlastňovaní nebude prípustné, aby začatie vyvlastňovacieho konania inicioval subjekt odlišný od subjektu, v prospech ktorého sa má uskutočnit' vyvlastnenie (napríklad na účet toho, v prospech koho sa má uskutočnit' vyvlastnenie). Nemôže teda iniciovat' vyvlastnenie pozemku pre účely miestnej komunikácie napríklad fyzická osoba, pretože aktívne legitimovaným subjektom vo veciach miestnych komunikácií je výlučne obec. Uvedený výsledok rozhodovacej činnosti súdov predstavuje významný korektív vo vzt’ahu k aplikačným problémom, ktoré vyvstávajú v relácii $\mathrm{k}$ inštitútu začatia vyvlastňovacieho konania.

Osobitné vyvlastňovacie predpisy môžu obsah pojmu „vyvlastnitel““ zúžit’. Dôvodom takejto reštrikcie môže byt' osobitý charakter vyvlastňovacích konaní upravených osobitnými vyvlastňovacími predpismi, a to so zretel'om predovšetkým na účel vyvlastnenia, dobu vyvlastnenia či rozsah vyvlastnenia. Tak napríklad subjektom, ktorý je oprávnený navrhnút' vyvlastnenie nehnutel'nosti vo verejnom záujme na účely obrany štátu podl'a zákona o obrane Slovenskej republiky v čase vojny alebo vojnového stavu, je výhradne Ministerstvo obrany SR. ${ }^{32}$ Úprava osobitných vyvlastňovacích predpisov je $\mathrm{v}$ tomto smere záväzná a kogentná. Pokial' by $\mathrm{v}$ uvedených prípadoch vo vyvlastňovacej praxi došlo $\mathrm{k}$ iniciovaniu začatia vyvlastňovacieho konania odlišným subjektom, vyvlastňovací orgán by vyvlastňovacie konanie nebol oprávnený uskutočnit' z dôvodu nedostatku návrhovej legitimácie. Opačný prípad by značil postup v rozpore s osobitným zákonom.

V porovnaní s úpravou návrhovej legitimácie vo vyvlastňovacom konaní v stavebnom zákone je účinná právna úprava formulovaná všeobecnejšie, i ked’ nateraz pravdepodobne len v právno-doktrinálnej rovine, teda bez závažnejších právno-aplikačných dopadov. Podla

29 Napríklad zákon č. 135/1961 Zb. o pozemných komunikáciách (cestný zákon) v znení neskorších predpisov, zákon č. 44/1988 Zb. o ochrane a využití nerastného bohatstva (banský zákon) v znení neskorších predpisov, zákon č. 51/1988 Zb. o banskej činnosti, výbušninách a o štátnej banskej správe v znení neskorších predpisov a d’alšie.

30 Teraz ustanovenie $§ 15$ ods. 1 zákona o vyvlastňovaní.

31 Rozsudok Najvyššieho súdu Slovenskej republiky sp. zn. 3Š̌p/20/2013 z 3. decembra 2013.

32 Ustanovenie $\S 23$ ods. 3 zákona o obrane Slovenskej republiky. 
ustanovenia $\S 112$ ods. 2 alinea 1 stavebného zákona sa vyvlastňovacie konanie začínalo na návrh orgánu štátnej správy, právnickej alebo fyzickej osoby, ktorá má predmet vyvlastnenia využit' na účel, na ktorý sa vyvlastňuje. Aj podl'a súčasnej úpravy bude nepochybne oprávneným iniciovat' vyvlastňovacie konanie orgán štátnej správy, právnická osoba alebo fyzická osoba, pokial' naplní normatívnu i judikatórnu požiadavku stotožnenia so subjektom, v prospech ktorého sa zamýšl’ané vyvlastnenie má realizovat'. Abstraktnejší charakter účinnej právnej úpravy by sa mohol de lege ferenda prejavit' napríklad v potenciálnej aktívnej legitimácii hmotnoprávneho nonsubjektu, pokial' by to osobitný vyvlastňovací predpis expressis verbis pripustil. ${ }^{33}$

\section{ZÁSADA LEGALITY VYVLASTŇOVACIEHO KONANIA A ZÁSADA „NIET VYVLASTNENIA BEZ VYVLASTŇOVACIEHO KONANIA“"}

Vyvlastňovacie konanie sa popri všeobecných zásadách správneho konania ${ }^{34}$ riadi osobitými zásadami, ktorých dodržanie je nevyhnutné v záujme zákonného priebehu a výsledku konania o vyvlastnení. Zásady vyvlastňovacieho konania doteraz vymedzuje a materiálne špecifikuje len právna doktrína, pretože zákon o vyvlastňovaní a ani predchádzajúce legislatívne úpravy vyvlastňovania $\mathrm{v}$ tomto smere neobsahujú úpravu. Tak napríklad M. Śtefanovič zásadami konania o vyvlastnení rozumie zásadu legality, zásadu uplatnenia dôležitého verejného záujmu, zásadu náhrady za vyvlastnenie, zásadu ochrany oprávnených záujmov doterajšieho vlastníka, zásadu povinného zistovania, zásadu súladu vyvlastnenia s cielmi a zámermi územného plánovania, zásadu vyvlastnenia pozemku len $v$ nevyhnutnom rozsahu a zásadu ochrany polnohospodárskeho pôdneho fondu. ${ }^{35}$

Zásada legality sa na účel vyvlastňovacieho konania prejavuje v skutočnosti, že vyvlastnit' možno len na základe zákona. ${ }^{36}$ Takéto vnímanie zásady legality možno označit' ako extenzívne, pretože môže zahŕňat' jednak (i) potrebu zákonnej formy materiálnej i formálnej reglementácie vyvlastnenia, a jednak (ii) neprípustnost' vyvlastnenia bez existencie skoršej finálnej formy činnosti vyvlastňovacieho orgánu (právoplatné rozhodnutie o vyvlastnení), t. j. nevyhnutnost' uskutočnenia vyvlastňovacieho konania so zretel'om na dosiahnutie účelu vyvlastnenia. Obsah zásady legality vyvlastňovacieho konania môže byt' vnímaný len v tom zmysle, že hmotnoprávna a procesnoprávna úprava vyvlastnenia musí byt' obsiahnutá (čo do právnej sily) na úrovni zákona. Takéto uplatnenie zásady legality môže byt' aktuálne $\mathrm{v}$ právnych poriadkoch, ktoré pripúšt’ajú vyvlastnenie zákonom bez uskutočnenia konania o vyvlastnení. V tomto prípade môže íst' o užšie poňatie zásady legality vyvlastřovacieho konania. Toto poňatie zásady legality vyvlastňovacieho konania by mohlo byt' aktuálne aj v slovenskom právnom poriadku, pokial' by $\mathrm{k}$ tejto zásade pristúpila samostatná a obsahovo osobitá zásada ,niet vyvlastnenia bez vyvlastňovacieho konania“. Takáto zásada by nemusela byt' len nesamostatnou zložkou zásady legality, pretože obe zásady môžu teoreticky existovat' nezávisle od seba, uplatňujúc sa jedna nezávisle a oddelitel'ne od druhej. Pokial' by napríklad právna úprava pripustila (čisto teoreticky) vyvlastnenie podzákonným predpisom, ale s nevyhnutnost'ou predošlého konania o vyvlastnení, vo vyvlastňovacom konaní by sa uplatnila len zásada ,niet vyvlastnenia bez vyvlastňovacieho konania“. Naopak, ak by z pohl'adu prameňov normatívnej úpravy vyvlastnenia existovala požiadavka regulácie vyvlastňovania výlučne zákonom, ale s možnost'ou vyvlastnit' bez vyvlastňovacieho konania, uplatnila by sa len zásada legality.

\footnotetext{
33 T. j. v návrhovej legitimácii subjektu, ktorý podl’a hmotného práva nedisponuje administratívou-právnou subjektivitou.

34 Pozri $\S 3$ - $§ 4$ správneho poriadku a bližšie KOŠIČIAROVÁ, S. Správny poriadok. Komentár. Šamorín: Heuréka, 2013, s. 22 a nasl.

35 ŠTEFANOVIČ, M. Pozemkové právo. 3. aktualizované vydanie. Bratislava: EUROUNION, 2010, s. 241 - 244.

36 tamže, s. 242.
} 
V slovenskom právnom poriadku sa de lege lata nepripúšt’a vyvlastnenie priamo zákonom, t. j. bez toho, aby prebehlo vyvlastňovacie konanie. ${ }^{37}$ Tento záver po aplikačnej stránke potvrdzujú aj závery najvyšších súdnych autorít - Ústavný súd SR už v ranom štádiu svojej činnosti k neprípustnosti vyvlastnenia zákonom uviedol, nasledovné: Ustanovenie čl. 20 ods. 4 Ústavy Slovenskej republiky uvádza, že: "Vyvlastnenie alebo nútené obmedzenie vlastníckeho práva je možné iba v nevyhnutnej miere, a to na základe zákona a za primeranú náhradu". Uvedené ustanovenie Ústavy Slovenskej republiky predpokladá existenciu zákona, na základe ktorého je možné uskutočnit' vyvlastnenie alebo nútené obmedzenie vlastníckeho práva. Ústava Slovenskej republiky neumožňuje, aby $k$ vyvlastneniu alebo nútenému obmedzeniu vlastníckeho práva došlo priamo zákonom (ako to napríklad umožňuje čl. 14 ods. 3 Základného zákona Spolkovej republiky Nemecko z 23. mája 1949 v znení neskorších predpisov: "Vyvlastnenie... sa smie uskutočnit' len zákonom alebo na základe zákona, ktorý upraví spôsob a rozsah odškodnenia."), ale na základe zákona. Z uvedeného vyplýva, že Národná rada Slovenskej republiky ako jediný ústavodarný a zákonodarný orgán Slovenskej republiky nie je v zmysle Ústavy Slovenskej republiky oprávnená priamo zákonom vyvlastnit' alebo nútene obmedzit' vlastnícke právo. ${ }^{38} \mathrm{~V}$ týchto intenciách sa teda v slovenskom právnom poriadku de lege lata uplatňuje zásada legality vyvlastňovacieho konania za súčasného uplatnenia zásady „niet vyvlastnenia bez vyvlastňovacieho konania“، ${ }^{39}$

\section{ZÁVER}

Aktuálne platná a účinná právna úprava $\mathrm{v}$ článku predostrených aspektov začatia konania o vyvlastnení vychádza z právno-aplikačne zásadne osvedčených inštitútov vyvlastňovacieho konania tak, ako boli upravené v stavebnom zákone. Zákon o vyvlastňovaní však súčasne prináša precizáciu právno-normatívnej základne vyvlastňovacieho procesu, zohl’adňujúc najmä závery administratívno-právnej vedy a opodstatnené požiadavky aplikačnej praxe.

Z pohl'adu možného lepšieho naplnenia požiadavky na zabezpečenie spravodlivého konania možno pozitívne zhodnotit' kvantitatívne a kvalitatívne modifikácie obsahových náležitostí návrhu na začatie konania o vyvlastnení. Teoreticky môže byt' prínosom aj abstraktnejšie právne ukotvenie návrhovej legitimácie vo vyvlastňovacom konaní. V tejto súvislosti ostáva pre d’alší výskum otvorená otázka procesného postavenia administratívnych hmotnoprávnych nonsubjektov, ktorá doposial' nebola komplexne vedecky spracovaná. Pokial' ide o konkurenciu začatia územného konania a vyvlastňovacieho konania, $\mathrm{v}$ súlade $\mathrm{s}$ konštantnou rozhodovacou činnost'ou možno ustálit', že začatie (a skončenie) konania o vyvlastnení nie je $\mathrm{v}$ nijakom prípade predpokladom začatia, prípadne pokračovania $\mathrm{v}$ už začatom územnom konaní.

37 Pokial' by sa de lege ferenda pripustilo vyvlastnenia zákonom, bolo by možné v závislosti od d’alších okolností uvažovat' o znárodňovaní. M. Sudzina ako jeden z rozdielov medzi vyvlastnením a znárodnením uvádza skutočnost', že k znárodneniu dochádza nie $\mathrm{v}$ administratívnom konaní na základe rozhodnutia správneho orgánu, ale priamo zo zákona bez vydania rozhodnutia. Pozri SUDZINA, M. Vyvlastňovanie pozemkov a stavieb a nútené obmedzenie vlastníckeho práva k nim. In VOJČÍK, P. - FILIČKO, V. - KOROMHÁZ, P. (eds.) Košické dni súkromného práva I. Košice: Univerzita Pavla Jozefa Šafárika v Košiciach, 2016, s. 295. B. Vlachová výstižne konštatuje, že kým k vyvlastneniu dochádza na základe správneho aktu, k znárodneniu na základe legislatívneho aktu. Pozri VLACHOVÁ, B. Zákon o vyvlastnění. Komentár. Praha: C. H. Beck, 2018, s. 9.

38 Nález Ústavného súdu Slovenskej republiky, PL. ÚS 38/95 z 3. apríla 1996.

39 Z historicko-komparatívneho hl'adiska možno uviest', že zákon o jednorazových mimoriadnych opatreniach v príprave niektorých stavieb dial’nic a ciest pre motorové vozidlá v znení účinnom do 26. júla 2011 pripúšşal výstavbu nehnutel'ností na cudzích pozemkoch (vo vlastníctve súkromných osôb) ešte pred odkúpením či vyvlastnením. $\mathrm{K}$ vyvlastneniu tu z materiálneho hladiska dochádzalo priamo zákonom, pričom vyvlastňovacie konanie sa do vysokej miery formalizovalo, t.j. redukovalo sa na konanie o výške náhrady za vyvlastnenie pozemku. Takáto úprava bola Ústavným súdom Slovenskej republiky posúdená ako protiústavná (nález Ústavného súdu Slovenskej republiky č. 235/2011 Z. z.). Pozri GRMAN, J. Verejný záujem ako ústavnoprávny a zákonný predpoklad vyvlastnenia. In Justičná revue, 2011, č. 5 , s. 707 a nasl. 
Popri vývojových tendenciách začatia konania o vyvlastnení som v článku prezentoval aj čiastkové úvahy o niektorých zásadách konania o vyvlastnení. Vzhl'adom nato, že vyvlastnenie sa v súčasnej i staršej civilistike tradične chápe ako najzávažnejši zásah do vlastníckeho práva ${ }^{40}$ by de lege ferenda nemuselo byt' na škodu veci explicitné vymedzenie (aspoň) základných zásad či základných princípov konania o vyvlastnení v úvode relevantného právneho predpisu. Po legislatívno-technickej stránke by sa to mohlo uskutočnit' bud' zakotvením niekol'kých článkov v úvode zákona (pred paragrafovým znením zákona), prípadne aspoň zavedením jedného paragrafového ustanovenia, ktoré by zavádzalo základné zásady konania o vyvlastnení vo viacerých odsekoch. Uskutočnenie týchto úvah sa však v blízkej budúcnosti pravdepodobne nejaví príliš reálne, a to najmä so zretel'om na pomerne „čerstvúu“ právnu úpravu vyvlastňovania. Uvedený fakt však nebráni realizácii d’alšieho výskumu a odborných či vedeckých diskusií v oblasti zásad vyvlastňovacieho konania, a to najmä so zretel'om na pomerne medzerovitú právno-vedeckú spracovanost' uvedenej problematiky.

\section{KLUUČOVÉ SLOVÁ}

vyvlastnenie, konanie o vyvlastnení, začatie konania o vyvlastnení, zásady konania o vyvlastnení.

\section{KEY WORDS}

expropriation, expropriation proceedings, commencement of expropriation proceedings, principles of expropriation proceedings.

\section{POUŽITÁ LITERATÚRA}

1. DOBROVIČOVÁ, G.: Právne normy. In: BRÖSTL, A. a kol.: Teória práva. Plzeň: Aleš Čeněk, 2013, 199 s. ISBN 978-80-7380-425-1.

2. FEČÍK, M.: Komentár k § 5 Správneho súdneho poriadku. In: BARICOVÁ, J. - FEČÍK, M. ŠTEVČEK, M. - FILOVÁ, A. a kol.: Správny súdny poriadok. Komentár. Bratislava: C. H. Beck, 2018, 1824 s. ISBN 978-80-7400-678-4.

3. FEKETE, I.: Občiansky zákonník. Vel'ký komentár. 2. zväzok (Vecné práva, Zodpovednost' za škodu a za bezdôvodné obohatenie). 2. aktualizované a rozšírené vydanie. Bratislava: Eurokódex, 2015, 902 s. ISBN 978-80-8155-040-9.

4. FILIČKO, V.: Zásada lex specialis a jej ne/správna aplikácia v súdnej praxi. Vedl'ajší účastník v exekučnom konaní. In: BRÖSTL, A. - BREICHOVÁ LAPČÁKOVÁ, M. - ŠTRKOLEC, M. (eds.): Základné zásady v rozhodovacej činnosti súdnej moci. Zborník vedeckých prác doktorandov. Košice: Univerzita Pavla Jozefa Šafárika v Košiciach, 2014, s. 266 - 274. ISBN 978-80-8152-120-1.

5. GOGOVÁ, M. - BUDJAČ, M.: Historický kontext formovania inštitútu vyvlastnenia a jeho reflexia de lege lata. In: Právny obzor, 91, 2008, č. 1, s. 47 - 71. ISSN 0032-6984.

6. GRMAN, J.: Verejný záujem ako ústavnoprávny a zákonný predpoklad vyvlastnenia. In: Justičná revue, 2011, č. 5, s. 704 - 719. ISSN 1335-6461.

7. JAKAB, R.: Priebeh správneho konania. In: JAKAB, R. - MOLITORIS, P.: Správne právo procesné. 2. aktualizované vydanie. Košice: Univerzita Pavla Jozefa Šafárika v Košiciach, 2018, 260 s. ISBN 978-80-8152-593-3.

40 VOJČÍK, P. Pojem a obsah vlastníckeho práva. In VOJČÍK, P. a kol. Občianske právo hmotné. Plzeň : Aleš Čeněk, 2012, s. 213. Zo staršej civilistiky v tomto zmysle prezentuje vyvlastnenie z právno-historického pohl'adu Štefan Luby vo svojom diele Dejiny súkromného práva na Slovensku. Pozri LUBY, Š. Dejiny súkromného práva na Slovensku. Bratislava: Iura Edition, 2002, s 383 a nasl. 
8. JANDERKA, K.: Zákon o vyvlastnění. Poznámkové vydání. Praha: Linde, 2009, 151 s. ISBN 978-80-7201-774-4.

9. KOŠIČIAROVÁ, S.: Správny poriadok. Komentár. Šamorín: Heuréka, 2013, 357 s. ISBN 978 80-89122-85-1.

10. LUBY, Š.: Dejiny súkromného práva na Slovensku. Bratislava: Iura Edition, 2002, 630 s. ISBN 80-89047-48-3.

11. SEMAN, T.: Správne právo hmotné. Všeobecná čast' II. Košice: Univerzita Pavla Jozefa Šafárika v Košiciach, 2006, 166 s. ISBN 80-7097-652-7.

12. SEMAN, T.: Verejná správa v správnom súdnictve. Košice: Univerzita Pavla Jozefa Šafárika v Košiciach, 2016, 180 s. ISBN 978-80-8152-424-0.

13. SUDZINA, M.: Vyvlastňovanie pozemkov a stavieb a nútené obmedzenie vlastníckeho práva k nim. In: VOJČ́́K, P. - FILIČKO, V. - KOROMHÁZ, P. (eds.): Košické dni súkromného práva I. Košice: Univerzita Pavla Jozefa Šafárika v Košiciach, 2016, s. 290 - 306. ISBN 978-80-8152400-4.

14. ŠKROBÁK, J.: Rozhodovacie procesy na úseku územného plánovania, stavebného poriadku a vyvlastňovania. In: VRABKO, M. a kol.: Správne právo procesné. Osobitná čast'. 2. aktualizované a doplnené vydanie. Šamorín: Heuréka, 2018, 382 s. ISBN 978-80-8173-049-8.

15. ŠTEFANOVIČ, M.: Pozemkové právo. 3. aktualizované vydanie. Bratislava: EUROUNION, 2010, 312 s. ISBN 978-80-89374-10-6.

16. VLACHOVÁ, B.: Zákon o vyvlastnění. Komentáŕ. Praha: C. H. Beck, 2018, 176 s. ISBN 97880-7400-036-2.

17. VOJČÍK, P.: Pojem a obsah vlastníckeho práva. In: VOJČÍK, P. a kol.: Občianske právo hmotné. Plzeň: Aleš Čeněk, 2012, 637 s. ISBN 978-80-7380-402-2.

\section{KONTAKTNÉ ÚDAJE AUTORA}

\section{Bc. Lukáš Tomaš}

Študent 1. ročníka magisterského stupňa štúdia

Univerzita Pavla Jozefa Šafárika v Košiciach, Právnická fakulta

Kováčska 26, 04001 Košice, Slovenská republika

E-mail: lukas.tomas@student.upjs.sk 